\title{
The Q Theory of Housing Investment
}

\section{By: G. DONALD JUD AND DANIEL T. WINKLER}

Jud, G. D. and Daniel T. Winkler. "The Q Theory of Housing Investment," Journal of Real Estate Finance and Economics, vol. 27, no. 3, 2003, pp. 379-92.

Made available courtesy of Springer Verlag: http://www.springerlink.com/content/102945/?p=843f9c8b001045628fc8b10026a53ed2\&pi=0

\section{The original publication is available at www.springerlink.com}

***Note: Figures may be missing from this format of the document

\begin{abstract}
:
This paper presents estimates of a Q model of housing investment, using quarterly data for the United States. The empirical model is estimated using building permits, housing starts, and housing investment expenditures as measures of investment. The current and lagged values of the $\mathrm{Q}$ ratio are found to be positively and significantly associated with housing investment, whichever way investment is measured. The findings suggest that the housing market indeed functions as Tobin has theorized. Housing suppliers appear to respond to the demands of housing consumers, building more new homes when existing home prices are high relative to new home prices.

Key Words: Q ratio, Q theory, housing investment

\section{Article:}

\section{Introduction}

More than three decades ago, James Tobin (1969, p. 21) put forth the idea that the "rate of investment ... should be related ... to q, the value of capital relative to its replacement cost." Tobin's idea, known widely as Tobin's Q ratio, has been extensively applied in the finance and economics literature, ${ }^{1}$ and the theoretical underpinnings of $\mathrm{Q}$ theory have been laid out formally by Hayashi (1982).

In the housing market, $\mathrm{Q}$ theory has not been widely applied, even though its application has been suggested by Tobin (Fettig, 1996). To the authors' knowledge, one paper has been published that directly tests $\mathrm{Q}$ theory as a determinant of housing investment, and this application is in a study of the housing investment in Finland by Takala and Tuomala (1990). They report that the Q ratio is a significant predictor of housing investment after 1980. The paucity of empirical studies of housing investment utilizing the $Q$ ratio derives from the unavailability of empirical data. In particular, until very recently, there has been no national series of quality-adjusted existing housing prices. While the Census Bureau for many years has published a quality-adjusted series for new home prices, the Office of Federal Housing Enterprise Oversight (OFHEO) only recently has made available the quality-adjusted existing housing price index developed from the Freddie Mac-Fannie Mae repeat transaction database.
\end{abstract}


This paper presents estimates of a Q theory model of housing investment using recently available data for the United States Section 2 of the paper examines neoclassical and real options investment models, Section 3 introduces the Q theory of housing investment, Section 4 discusses the data and empirical results, and Section 5 summarizes the relevant findings.

\section{Investment models}

The investment housing literature includes research employing (1) neoclassical models and (2) real options models with uncertainty. Q theory and the user cost of capital approach (Jorgenson, 1963) are considered static models because they do not include dynamic elements such as adjustment costs, delivery lags, and the value of real options.

\subsection{Neoclassical models}

A predecessor of Tobin's Q is a neoclassical investment model by Jorgenson (1963); this theory compares the marginal product of capital with its rental cost. In this model, the rental cost defines the user cost of capital. The user cost of capital is determined by parameters such as the purchase price, the opportunity cost of funds, as well as depreciation and taxes. As long as the marginal product exceeds the user cost of capital, the firm will continue to invest, and it will stop when the two are equal.

Q theory is a neoclassical investment model that posits that investment in any asset is a function of the $\mathrm{Q}$ ratio: the ratio of the market valuation of the asset to its replacement cost (or marginal cost). If $Q>1$, then a firm should invest; investment should stop when a firm's marginal $Q=1$. If $\mathrm{Q}<1$, the firm should not invest because the cost of acquiring an asset in the market is less costly than its purchase (replacement) cost. If the market value of a project is not directly observable through the market, it can frequently be computed as the expected present value of net cash flows.

\subsection{Real options and uncertainty}

Abel (1983) and Abel and Eberly (1994) recognized that uncertainty could affect investment decisions through Tobin's Q. ${ }^{2}$ More recently, Caballero and Leahy (1996), support the contention that Tobin's Q can be an insufficient indicator of investment potential in the presence of fixed costs of adjustment and a non-perfect competition environment. Lehmann (1997) and Bo (1999) have developed Q models for financial markets under the assumptions of uncertainty.

Dixit and Pindyck (1994) compare the real options approach with the neoclassical investment theory (including Q theory) and solve the firm investment problem using a dynamic programming and contingent claims framework. ${ }^{3}$ They develop a perpetual investment model where the optimal investment rule is to invest if the market value of the project is greater than a threshold $\left(\mathrm{V}^{*}\right)$ value (where $\left.\mathrm{V}^{*}=\beta_{1} /\left(\beta_{1}-1\right)\right] \mathrm{I}$, I is investment, and $\beta_{1}$ a function of the risk-free rate, the dividend yield, and the rate of variation in project value). The term in brackets is always greater than 1 and increases with economic uncertainty. Abel et al. (1996) extend the Q theory and option price approaches. In a two period context, Q is separated into three components including the expected present value of the marginal returns to capital evaluated at the firstperiod capital stock (assuming that the capital stock remains constant at that level in the future), the marginal put option (to sell capital) in period 2, and the marginal call option (option to buy capital in period 2). The put option occurs because when a firm installs capital that it may resell, 
it acquires a put option, and if it can purchase capital later, it has a call option. The call option has a negative sign, and it is subtracted because investing removes this option. ${ }^{4}$

This study examines the Q theory as it pertains to housing investment. Recent literature suggests that while real options do not invalidate Q theory, they may provide an additional explanation for investment.

\section{The $Q$ theory of housing investment}

$\mathrm{Q}$ theory posits that investment in any asset is a function of the $\mathrm{Q}$ ratio: the ratio of the market valuation of the asset to its replacement cost (or marginal cost). In the case of housing, arbitrage by consumers between new- and existing-housing markets is what drives housing investment. If, for example, existing homes are expensive relative to new homes, then housing consumers will demand more new homes. Alternatively, if existing homes are cheap relative to new homes then consumers will buy more existing homes and fewer new homes. In a competitive environment, where builders and developers (housing suppliers) are price takers, suppliers respond to the demands of housing consumers, building new homes when existing home prices are high relative to new homes.

The relative housing price between existing and new homes is related to efficiency of housing markets, which has been examined by applying discount versions of housing price present value. Meese and Wallace (1994) find evidence that long-run results are consistent with the housing price present value relation when considering tax rates and borrowing costs. In the short run, this relation is rejected more likely as a result of high transactions costs rather than because of bubbles or irrational behavior. Dipasquale and Wheaton (1994) find that the price adjustment process is gradual for single-family housing; housing demand is found to be more sensitive to housing price levels and less sensitive to annual user costs. Rosenthal (1999) argues that present value studies of housing market efficiency are prone to controversy because housing prices are compared to unobserved discount streams of future rents. He examines two equilibrium conditions that depend only on current and past values. Urban landowners hold a call option to develop property, and builders must purchase such an option by acquiring a parcel of land. When the net profit from developing today is more than the cost of the option, landowners will exercise their development option. In an efficient market, a previously developed property with an existing building has zero value when it is sold for redevelopment because the existing building is demolished upon sale. This creates a zero-profit condition for builders because the development option is embedded in a property both before and after redevelopment. In the second equilibrium condition, Rosenthal argues that because there is a lag between the time the builder starts a project and when a newly developed property is ready for sale, it is not possible for them to earn excess profits from contemporaneous information because building prices converge back to construction costs faster than construction lags. In short, in long-run equilibrium, the price of new construction not only depends upon current construction costs, but also on past and current values of the relative cost of vacant land to capital. Rosenthal finds that residential housing markets are efficient. New building price shocks do not have a discernable effect on construction costs and dissipate in two quarters. Different vintage buildings appear to converge back to equilibrium at the same rate suggesting they are close substitutes and provide equal expected returns. These studies in aggregate tend to support the use of a $\mathrm{Q}$ ratio as a measure of housing investment equilibrium. 
Hayashi (1982) shows that Q theory is based on the concept of a marginal Q. Empirical estimates of the Q ratio measure the average Q. However, if housing suppliers are price takers with constant returns to scale, then marginal $\mathrm{Q}$ is equal to average $\mathrm{Q}$.

Topel and Rosen (1988) point out that Q theory assumes that investment decisions are myopically determined because builders are assumed to compare current asset prices with current marginal costs of production (replacement cost). Kydland and Prescott (1982) show that the idea that current prices embody all the information necessary for investment decisions assumes that short- and long-run supply coincide. However, if short-run supply is less elastic than long-run supply (because it takes time to transfer factors of production), then current prices will no longer be sufficient for investment decisions. ${ }^{5}$ In this case, builders must form expectations of future prices in making current production decisions. Summers (1981) demonstrates that the current $Q$ ratio as well as past values of $Q$ affect investment when shortand long-run supply are not identical.

In the empirical section that follows, we test the significance of current and lagged values of Q. The Q model of housing investment is written as follows:

$$
I_{t}=I\left(Q_{t}, Q_{t-1}, Q_{t-2}, \ldots, Q_{t-n}\right)
$$

where, It is the housing investment in period $t$ is the Qt is the Q ratio in period t defined as the ratio of existing- to new-home prices. ${ }^{6}$

\section{Data and empirical results}

Data for the numerator of the Q ratio are obtained from the OFHEO price index for existing homes. OHHEO's House Price Indexes are available at the national and regional levels. The indexes track average house price changes in repeat sales or refinancings on the same singlefamily properties and are based on analysis of data obtained from over 11.9 million repeat transactions over the past 20 years (OFHEO, 1999). New home prices (the denominator of the Q ratio) are obtained from the Census Bureau's quality adjusted series for new home prices. The $\mathrm{Q}$ ratio data are defined on a quarterly basis.

Housing investment is modeled using three series: (1) the number of single-family residential building permits, (2) the number of single-family residential building starts, and (3) the real dollar value (billions of chained 1996 dollars) of housing investment in single-family structures as estimated in the quarterly national income and product accounts (NIDA). All of the data are quarterly. Permits and starts are obtained from the Census Bureau. Data on the dollar value of housing investment are taken from the U.S. Department of Commerce, Bureau of Economic Analysis (BEA). Table 1 shows the descriptive statistics for all of the variables used in the analysis.

The availability of data constrain the time-series and regional distribution of sample observations, making it possible to conduct the analysis only using national data back to the 1970s. The Census Bureau's index of new home prices is available on a quarterly basis only at the national level, thus, limiting the tabulation of the $\mathrm{Q}$ ratio for smaller regional areas of the 
country. OFHEO's index of existing home prices, which is available for a large number of MSAs, is tabulated only back to the mid-1970s, which constrains the time series. BEA's housing investment series for single-family homes extends only back to 1987, further limiting the time series for the housing expenditure data from the NIDA series.

Figure 1 plots the housing Q ratio from 1979 through 2000, using quarterly data. The Q ratio displays an upward drift, indicating that existing housing prices have increased faster than new home prices. In 1979.1, the existing house price index was 91.6. By 2000.4, the index had risen to 250.8 , recording a gain of 173.8 percent. During the same period, the new home price index grew from 51.4 to 117.9 , an increase of 129.4 percent.

The differences in the trends of the new- and existing-home indexes stem from differences in coverage and weighting. The existing home index includes only detached

Table 1. Descriptive statistics.

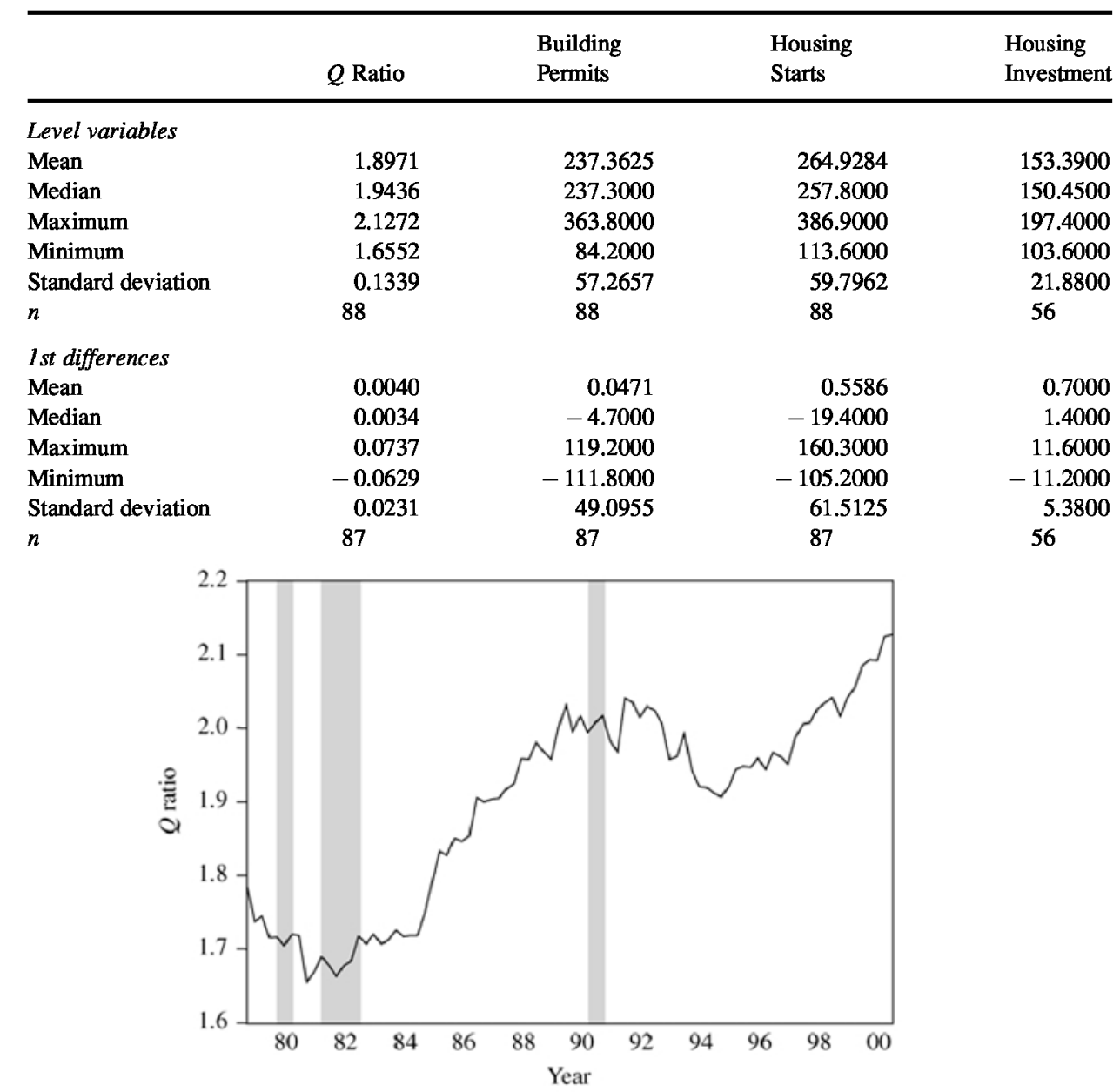

Figure 1. Housing $Q$ - ratio from $1980-2000$.

housing units; whereas, the new home index includes detached and attached housing units. A total of 10.5 percent of the new home index is composed of attached homes. The two indexes also weight regional areas differently when compiling the totals for the national indexes. The 
existing home index bases its weights on the stock of owner-occupied housing units reported in the 1990 Census. The new home index bases its weights on home building activity in 1996. The result is that the new home index gives much less weight to the Northeast and Midwest and more weight to the Southand West.

The calculated Q ratio displays a distinct cyclical pattern in addition to its positive longterm trend. The Q ratio declined substantially during the early 1980s and again in the early 1990s, displaying a tendency to fall during periods of economic weakness and rise during expansions.

Figures 2 and 3 plot the Q ratio against building permits and housing starts respectively. The plots are shown on a normalized scale, employing seasonally adjusted data for permits and starts. Overall, the plots reveal a reasonably close correspondence between the Q ratio and the two measures of housing activity. The greatest divergence occurs during the economic downturn of the early 1990s, when the Q ratio declined much less than did building activity.

The permit and start series used in this analysis are seasonally unadjusted. To allow for seasonal variation in these series, quarterly dummy variables are included in the permit and start models. The quarterly dummy variables are Qtr (1), Qtr (2), and Qtr (3), representing the 1st, 2nd, and 3rd quarters respectively.

Augmented Dickey-Fuller tests were conducted on the variables shown in Table 1 to determine the presence of unit roots. Table 2 shows the results of the unit root tests. The tests are conducted with two lagged 1st differences and employ three alternative specifications of the test equation: (1) no intercept or trend, (2) intercept, and (3) intercept

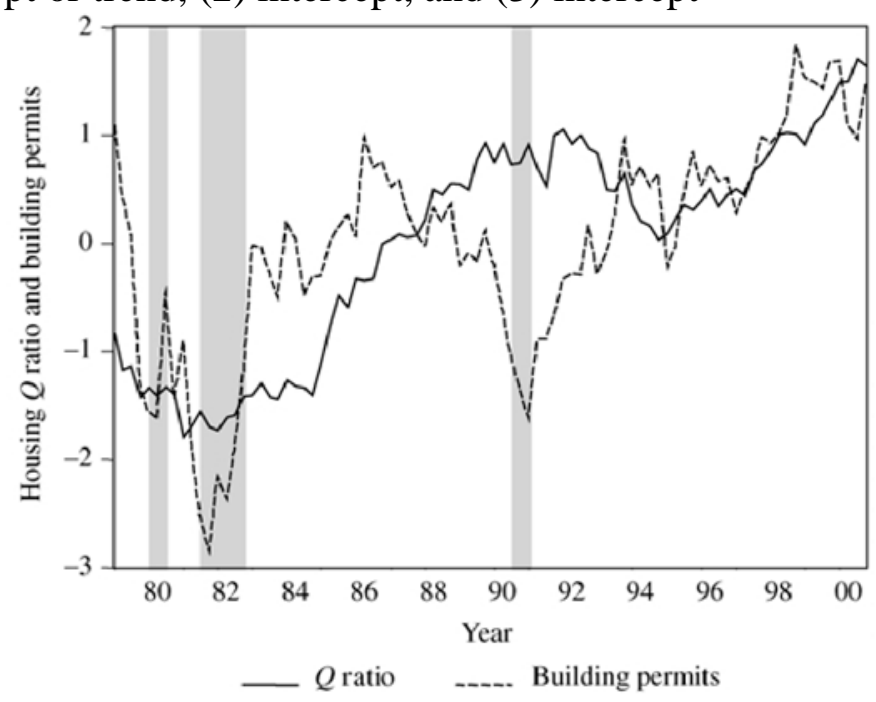

Figure 2. Relationship between the housing $Q$ ratio and building permits (normalized scale).

and trend. All of the variables have unit roots in levels, but not in 1st or 2nd differences. The level variables in Table 1, thus, are all non-stationary, that is, they display substantial, but unpredictable, upward trends over time. Ordinary least squares (OLS) is inappropriate for nonstationary series because the regression residuals tend also to be non-stationary. 
Engle and Granger (1987) show that two or more non-stationary series may be said to be cointegrated if a stationary linear combination of the two or more series can be found. Cointegrated time series have the desirable property that coefficient estimates of

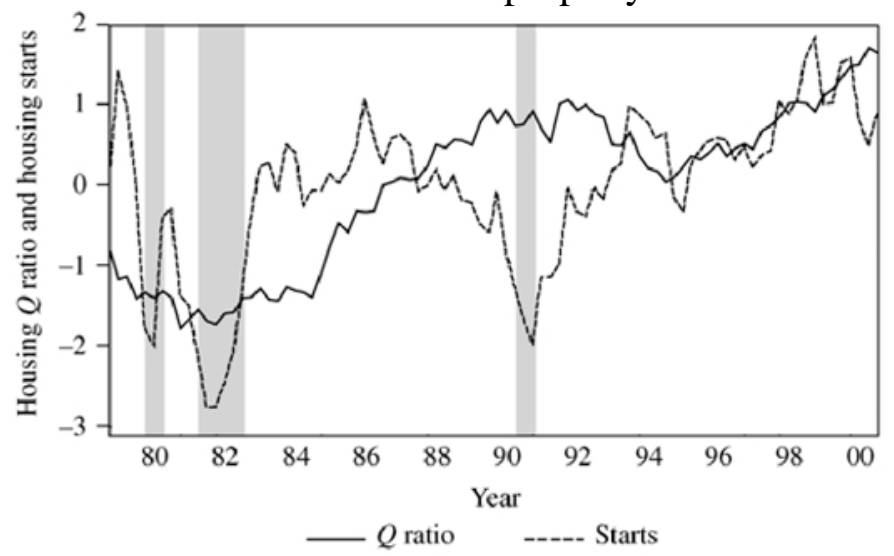

Figure 3. Relationship between the housing $Q$ ratio and housing starts (normalized scale).

Table 2. Augmented Dickey-Fuller tests for unit roots.

\begin{tabular}{|c|c|c|c|c|}
\hline Test for: & $Q$ Ratio & $\begin{array}{l}\text { Building } \\
\text { Permits }\end{array}$ & Housing Starts & $\begin{array}{l}\text { Housing } \\
\text { Investment }\end{array}$ \\
\hline \multicolumn{5}{|c|}{ With no intercept or trend } \\
\hline Levels & 2.0597 & -0.1358 & -0.3711 & -0.4989 \\
\hline 1st differences & -4.6957 & -11.9775 & -13.7538 & -3.7868 \\
\hline 2nd differences & -10.4782 & -28.3120 & -30.7269 & -5.1484 \\
\hline \multicolumn{5}{|l|}{ With intercept } \\
\hline Levels & -0.0474 & -1.7368 & -2.5781 & -0.8960 \\
\hline 1st differences & $-\mathbf{5 . 1 8 3 4}$ & -11.9403 & -13.6696 & $-\mathbf{3 . 8 2 0 9}$ \\
\hline 2nd differences & -10.4216 & -28.1639 & $-\mathbf{3 0 . 5 4 2 3}$ & $-\mathbf{5 . 0 9 1 2}$ \\
\hline \multicolumn{5}{|c|}{ With intercept and trend } \\
\hline Levels & -1.4186 & -3.4335 & -3.7906 & -2.4939 \\
\hline 1st differences & -5.1495 & -11.9152 & $-\mathbf{1 3 . 7 0 8 5}$ & $-\mathbf{3 . 9 7 5 4}$ \\
\hline 2nd differences & $-\mathbf{1 0 . 3 5 9 0}$ & -28.1378 & $-\mathbf{3 0 . 4 3 3 6}$ & $-\mathbf{5 . 0 5 6 4}$ \\
\hline$n$ & 88 & 88 & 88 & 56 \\
\hline
\end{tabular}

Notes. Test statistics in bold type indicate rejection of the null hypothesis of a unit root at the 0.01 level or above. All test include two lagged 1st differences.

cointegrated variables converge to the true estimates faster than coefficient estimates for variables that are not cointegrated.

Following the procedure developed by Johansen (1995), we conducted a series of cointegration tests using the group of variables listed in Table $1 .^{7}$ In the cointegration tests, housing investment is measured alternatively by (1) building permits, (2) housing starts, and (3) housing investment (from NIDA). The Johansen procedure considers five alternative assumptions regarding the presence of intercept and trend in the tests, and the test vector autoregression (VAR) equation is 
estimated with two period lags. The results of the cointegration tests are shown in Table 3. The null hypothesis of no cointegration is not rejected at the 1-percent confidence level in any of the tests reported in Table 3.

Because the variables of interest are not cointegrated but do have unit roots when measured in levels, we conclude that the basic model expressed in equation (1) can properly be estimated in first-difference form:

$$
\Delta I_{t}=I\left(\Delta Q_{t}, \Delta Q_{t-1}, \Delta Q_{t-2}, \ldots, \Delta Q_{t-n}\right)
$$

Equation (2) is estimated with the lag structure that maximizes the adjusted $\mathrm{R}^{2}$ of the estimated investment equation. To correct for the autocorrelation of residuals in the model withthe housing investment series from the NIDA as the dependent variable, ARMA terms [AR(p)] are included in the regression models. 


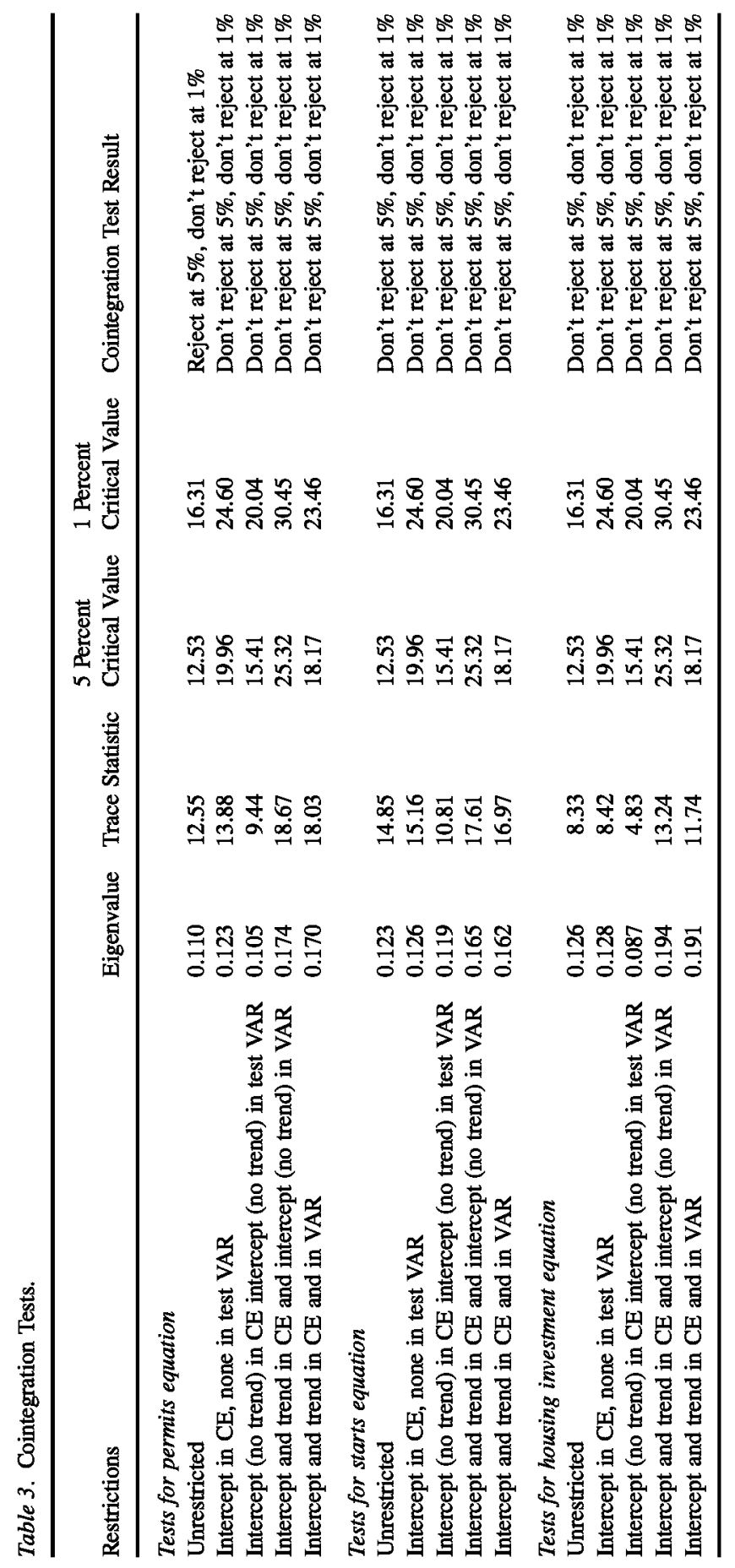


Table 4. $Q$ models of housing investment (dependent variables in 1 st difference form).

\begin{tabular}{lllllll}
\hline Variable & Building Permits & $T$-value & Housing Starts & $T$-value & Housing Investment & $T$-value \\
\hline Constant & -52.85 & -10.27 & -59.06 & -11.57 & 0.16 & 0.11 \\
$\Delta Q_{t}$ & 144.10 & 1.25 & 148.87 & 1.31 & n.a. & n.a. \\
$\Delta Q_{t-1}$ & 203.77 & 1.77 & 312.26 & 2.74 & 47.56 & 2.08 \\
$\Delta Q_{t-2}$ & 131.79 & 1.17 & 117.02 & 1.05 & 69.45 & 3.05 \\
$Q$ tr. 1 & 57.36 & 7.86 & 35.50 & 4.90 & n.a. & n.a. \\
Qtr. 2 & 119.90 & 16.25 & 150.81 & 20.60 & n.a. & n.a. \\
Qtr. 3 & 28.54 & 4.11 & 39.30 & 5.70 & n.a. & n.a. \\
AR(1) & n.a. & n.a. & n.a. & n.a. & 0.60 & 5.31 \\
$F$-test $(Q$ variables) & 5.40 & & 7.97 & & 9.41 & \\
Adj. $R^{2}$ & 0.79 & & 0.86 & & 0.37 & \\
Start time period & 1979.4 & & 1979.4 & & 1987.3 & \\
End time period & 2000.4 & & 2000.4 & & 2000.4 & \\
Number of obs. & 87 & & 85 & & 54 & 0.80 \\
LM test & 1.96 & & 1.45 & &
\end{tabular}

To test for serial correlation in the estimated models, we utilize the Breusch-Godfrey Lagrange multiplier (LM) test (Greene (1990)). The null hypothesis of the LM test is that there is no serial correlation up to a lag order $\mathrm{p}$, where $\mathrm{p}$ is pre-specified integer. The LM test statistic is asymptotically distributed as a chi square (p). The order $\mathrm{p}$ of the calculated LM tests is three in all the reported tests.

In the estimated 1 st difference $\mathrm{Q}$ models shown in Table 4, the adjusted $\mathrm{R}^{2} \mathrm{~s}$ indicate that the $\mathrm{Q}$ ratio explains a substantial portion of the variation in housing investment in each of the three estimated models. The LM tests suggest acceptance of the null hypothesis of no autocorrelation for the three housing models. To test the statistical significance of the Q terms, we report the computed F-values for tests of the joint significance of the Q variables. The F-tests reveal that the Q variables are significant in each of the three estimated investment models at the 0.05-level or better. The fitted and actual values for the three investment models are shown in the Appendix, Figures A.1-A.3.

\section{Summary and evaluation}

This paper presents estimates of a Q model of housing investment. The model is estimated using building permits, housing starts, and housing investment expenditures as measures of investment. The current and lagged values of the Q ratio are found to be positively and significantly associated with housing investment, whichever way it is measured.

The findings presented here suggest that the housing market indeed functions as Tobin has theorized. Housing suppliers appear to respond to the demands of housing consumers, building more new homes when existing home prices are high relative to new home prices. 
Appendix

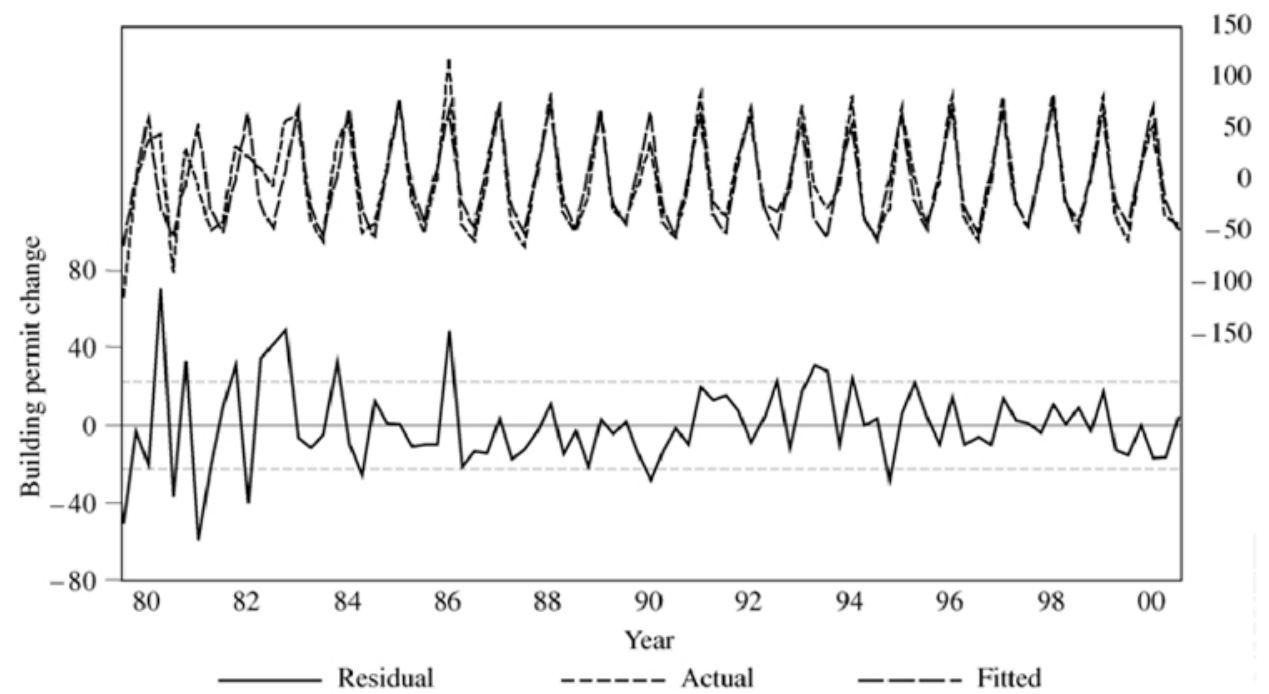

Figure Al. Change in residential building permits.

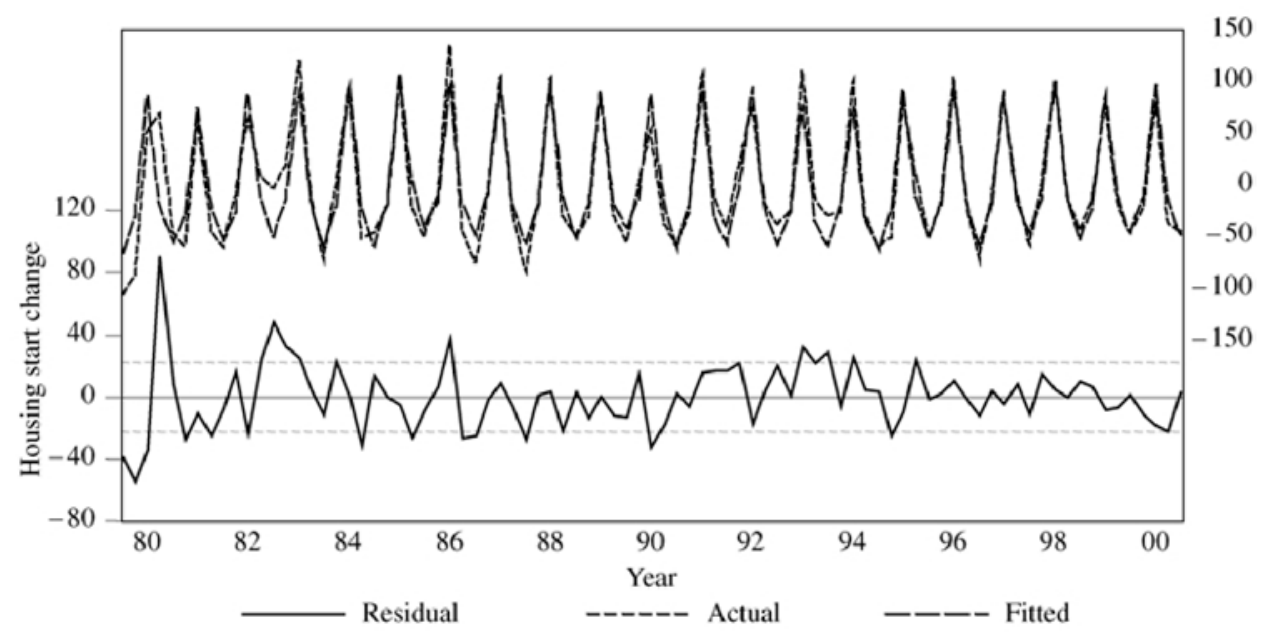

Figure A2. Change in housing starts. 


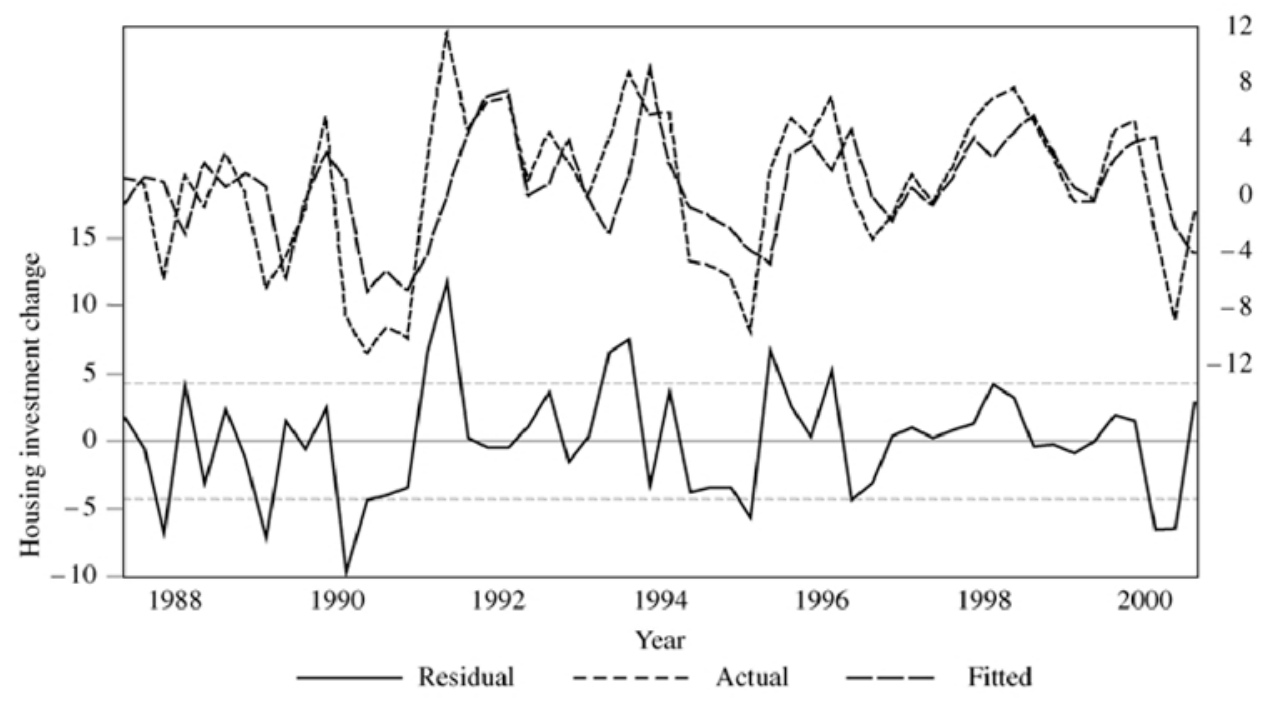

Figure A3. Change in housing investments, NIPA Accounts.

\section{Acknowledgments}

We are indebted to Paloma Taltauvall de La Paz (Universidad de Alicante) for her helpful suggestions on an earlier draft. We also want to thank the anonymous referees for their insightful comments. Any errors or omissions, however, are our responsibility.

\section{Notes}

1. See, for example, Schaller (1990), and Wildasin (1984).

2. Abel and Eberly $(1993,1994)$ find that uncertainty has a nonnegative effect on investment for a firm in a competitive marketplace even in the presence of irreversibility. However, empirical results by Guiso and Parigi (1999) support a negative relationship between investment and uncertainty; firms with higher perceived uncertainty are less responsive to increases in expected future demand, and therefore, they invest less.

3. Leahy and Whited (1996) have empirical evidence supporting the role of options in investment decisions in a variety of industries holding constant Tobin's Q; total risk is statistically significant and inverse to investment, and it is more important than systematic risk only. Guiso and Parigi (1999) find a negative relationship between investment and uncertainty; firms with higher perceived uncertainty are less responsive to increases in expected future demand, and therefore, they invest less.

4. Recent research offers empirical evidence supporting the role of real options in real estate. Holland, et al. (2000) examine option-based investment models to investigate whether uncertainty affects the rate of investment for commercial real estate. They find a short-term negative relationship between total uncertainty and rate of investment when holding constant built—asset price, systematic risk, and other factors, and that investors consider irreversibility and delay to be important considerations in their decision making. Somerville (2001) models the relationship between building permits and starts in a realoption framework. He finds that only in cases of large changes in market conditions do builders respond in deciding whether or not to exercise permits, consistent with a real option framework. However, his results indicate that uncertainty of returns is not important in explaining the time of completion, suggesting 
that the important stage to evaluate the option may be before the drawing of a building permit. Downing and Wallace (2001) argue that homeowners option to augment attributes of an existing house can be viewed as a real option; they find there is considerable regional variation of the effect of net investment return volatility on remodeling investment.

5. Blackley (1999) estimates long-run price elasticity of new housing supply to range from 1.6 to 3.7; this estimate is relatively high compared to esimtates by Poterba (1984), Topel and Rosen (1988), and DiPasquale and Wheaton (1994). Poterba (1984) and Topel and Rosen (1988) suggest that construction costs could be endogenous but they are not able to find effective instruments for these costs. Somerville (1999) finds that construction costs are inversely related to housing starts using a quality-controlled hedonic construction cost series and correcting for measurement error in labor costs and treating construction costs as endogenous.

6. Because the empirical model defines $\mathrm{Q}$ in terms of changes, in boththe numerator and the denominator, relative to a base year of 100 , this ratio indicates the increase or decrease in the $\mathrm{Q}$ ratio from the base year.

7. For an example of this approach, see Hamilton (1994), pp. 610-612.

\section{References}

Abel, A. B. (1983). "An Intertemporal Model of Saving and Investment," Econometrica 51, 675692.

Abel, A. B., and J. C. Eberly. (1994). "A Unified Model of Investment Under Uncertainty," American Economic Review 84, 1369-1384.

Abel, A. B., A. K. Dixit, J. C. Eberly, and R. S. Pindyck. (1996). "Options, the Value of Capital, and Investment," The Quarterly Journal of Economics 111, 753-777.

Abel, A. B., and J. C. Eberly. (1999). "The Effects of Irreversibility and Uncertainty on Capital Accumulation," Journal of Monetary Economics 44, 339-377.

Blackley, D. M. (1999). "The Long-Run Elasticity of New Housing Supply in the United States: Empirical Evidence for 1950-1994," Journal of Real Estate Finance and Economics 18, 25-42.

Bo, H. (1999). "The Q Theory of Investment: Does Uncertainty Matter?" Working Paper, University of Groningen.

Caballero, R. J., and J. V. Leahy. (1996). "Fixed Costs: The Demise of Marginal q." Working Paper No. 5508, National Bureau of Economic Research.

DiPasquale, D., and W. C. Wheaton. (1994). "Housing Market Dynamics and the Future of Housing Prices," Journal of Urban Economics 35, 1-27.

Dixit, A. K., and R. S. Pindyck. (1994). Investment Under Uncertainty. Princeton, NJ: Princeton University Press, 1994. 
Downing, C., and N. Wallace. (2000). "A Real Options Approach to Housing Investment," Summer Institute, National Bureau of Economic Research.

Engle, R. F., and C. W. J. Granger. (1987). "Co-integration and Error Correction:

Representation, Estimation, and Testing," Econometrica 55, 251-276.

Fettig, D. (1996). "Interview with James Tobin," Federal Reserve Bank of Minneapolis, The Region 10, 1-15.

Greene, W. H. (1990). Econometric Analysis. New York: Macmillan.

Guiso, L., and G. Parigi. (1999). "Investment and Demand Uncertainty," The Quarterly Journal of Economics 114,185-227.

Hamilton, J. D. (1994). Time Series Analysis. Princeton: Princeton University Press.

Hayashi, F. (1982). "Tobin's Marginal q and Average q: A Neoclassical Interpretation," Econometrica 50, 213- 224.

Holland, A. S., S. H. Ott, and T. J. Riddiough. (2000). "The Role of Uncertainty in Investment: An Examination of Competing Investment Models Using Commercial Real Estate Data," Real Estate Economics 28, 33-64.

Johansen, S. (1995). Likelihood-based Inference in Cointegrated Vector Autoregressive Models. Oxford: Oxford University Press.

Jorgenson, D. W. (1963). "Capital Theory and Investment Behavior," American Economic Review 53, 247-259.

Kydland, F. F., and E. C. Prescott. (1982). "Time to Build and Aggregate Fluctuations," Econometrica 50, 1345- 1370.

Leahy, J. V., and T. M. Whited. (1996). "The Effect of Uncertainty on Investment: Some Stylized Facts," Journal of Money, Credit and Banking 28, 64-83.

Lehmann, S. D. (1997). "Investment Under Uncertainty and Financial Market Development: A q-Theory Approach." Working Paper No. 17, Central Bank of Chile.

Meese, R., and Wallace, N. (1994). "Testing the Present Value Relation for Housing Prices: Should I Leave My House in San Francisco?" Journal of Urban Economics 35, 245-266.

Office of Federal Housing Enterprise Oversight (OFHEO). House Price Index, 3rd Quarter, 1999.

Poterba, J. M. (1984). "Tax Subsidies to Owner-Occupied Housing: An Asset Market Approach," The Quarterly Journal of Economics 99, 729-752. 
Rosenthal, S. S. (1999). "Residential Buildings and the Cost of Construction: New Evidence on the Efficiency of the Housing Market," The Review of Economics and Statistics 81, 288-302.

Schaller, H. (1990). "A Re-Examination of the Q Theory of Investment Using U.S. Firm Data," Journal of Applied Econometrics 5, 309-325.

Somerville, C. T. (1999). "Residential Construction Costs and the Supply of New Housing: Endogeneity and Bias in Construction Cost Indexes," Journal of Real Estate Finance and Economics 18, 43-62.

Somerville, C. T. (2001). "Permits, Starts, and Completions: Structural Relationships Versus Real Options," Real Estate Economics 29, 161-190.

Summers, L. H. (1981). "Taxation and Corporate Investment: A q-Theory Approach," Brookings Papers on Economic Activity 1, 67-127.

Takala, K., and M. Tuomala. (1990). "Housing Investment in Finland," Finish Economic Papers 3, 41-53.

Tobin, J. (1969). "A General Equilibrium Approach to Monetary Theory," Journal of Money, Credit, and Banking 1, 15-29.

Tobel, R., and S. Rosen. (1988). "Housing Investment in the United States," Journal of Political Economy 96, 718-740.

Wildasin, D. (1984). "The q Theory of Investment with Many Capital Goods," American Economic Review 74, 203-210. 